\title{
Effect of Preservatives and Temperature on Microbial and Physico-Chemical Attributes of Minimally Processed Pineapple
}

\author{
K.P. Sudheer*, K.B. Sankalpa and S. Saranya \\ Department of Agricultural Engineering, College of Horticulture, Kerala Agricultural \\ University, Thrissur-680656, India \\ *Corresponding author
}

\section{A B S T R A C T}

\section{Keywords \\ Minimal processing, Pineapple, preservatives, storage condition and shelf life \\ Article Info \\ Accepted: \\ 07 January 2019 \\ Available Online: \\ 10 February 2019}

\begin{abstract}
Minimally processed fruits are one of the major growing segments in food retail markets. However minimal processing leads to limited shelf-life due to excessive tissue softening and cut surface browning. Pineapple ( $c v$. Mauritius) tidbits were treated with various preservatives of different combination and stored in ambient and refrigerated storage condition. It was evident from the result that, as the storage period increases the colour values of $\mathrm{L}^{*}, \mathrm{a}^{*}$ and $\mathrm{b}^{*}$ were decreased irrespective of treatments. Reduction in colour values was due to development of translucent appearance of the fruit flesh, which changed from a yellow-white opaque colour to a translucent yellow colour. A better firmness was maintained in refrigerated storage condition in combination of calcium chlorideand citric acid treated sample. The decreasing trend was observed in $\mathrm{pH}$ value of treated samples compared to control sample. Vitamin C content was better retained in the presence of calcium chloride at refrigeration condition. Best samples were selected based on better retention of physic-chemical attributes, and selected sample was microbially safe up to twelve days of refrigerated storage condition.
\end{abstract}

\section{Introduction}

Minimal processing is defined as the handling, preparation, packaging and distribution of agricultural commodities in a fresh-like state. Minimal processing may include processes such as dicing, trimming, washing, cutting, grating, shredding, pulling the leaves off, etc. and packing and storing in polymeric films. This kind of plant food is named fresh-cut or ready-to-eat food (O'connor-shaw et al., 1994). Minimally processed fruits are one of the major growing segments in food retail markets. However, the greatest hurdle to commercial marketing is their limited shelf-life, which is due to excessive tissue softening and cut surface browning. Contact of enzymes and substrates in cut fruits lead to biochemical changes such as enzymatic browning, off-flavour and texture breakdown which reduce product quality and shelf-life (Manolopoulou and Varzakas, 2011). Minimal processing may increase microbial spoilage of fruit through transfer of skin microflora to fruit flesh where microorganisms can grow rapidly upon exposure to nutrient laden juices. Therefore it need an integrated approach, where raw 
material handling, processing packaging and distribution must be properly considered to make shelf life extension.

Various approaches are now applied to arrest the enzymatic browning which mainly include chemicals inhibitors and modified atmospheric packaging. Chemicals of different groups like reducing agent, inorganic salts and chelating agents exhibits various modes of action. Various chemical inhibitors are antimicrobials (sodium metabisulphite, calcium lactate, citric acid), antibrowning agents (ascorbic acid, acetyl cysteine, potassium sorbate, citric acid, carboxylic acid, 4-hexylsorcino, oxalic acid) and firming agents (calcium lactate, calcium chloride, calcium propionate, calcium ascorbate) (Siddiqui et al., 2011).

Pineapple is a popular fruit from tropical and subtropical regions, available throughout the year and widely consumed around the world. India is the sixth largest producer of pineapples in the world. Pineapple (Ananas comosus) is a non-climacteric fruit appreciated for its flavor, juiciness, texture, vitamin $\mathrm{C}$ and fiber content. However, slicing leads to an increase in the metabolic process and results in significant changes in their textural, color and flavour properties (Benitez et al., 2012).

The combined effect of hurdle technology with chemical preservatives and optimum storage condition might ensure the quality and safety of minimally processed pineapple until the consumption. Controlling product temperature during refrigerated storage is of critical importance, an optimum storage condition maintains the visual quality of fresh cut pineapple and reduces their respiration rate, tissue softening and microbial spoilage (Benitez et al., 2012). As per the available literature, choice of preservatives and temperature of storage critically influenced the shelf life of pineapple. Therefore in present study different preservatives and storage conditions were analysed for their ability to improve the shelf life of fresh cut pineapple fruit.

\section{Materials and Methods}

Pineapple was washed in tap water and treated with $120 \mathrm{ppm}$ of sodium hypochlorite for surface decontamination. Whole pineapple fruit was immersed in water containing 120 ppm sodium hypochlorite for $15 \mathrm{~min}$. Solution was drained and pineapple was peeled and cut into pieces of one centimeter thickness (Siddiqui et al., 2011).

Chemical preservative pretreatment was used in fresh cut pineapple fruits for controlling decay, reducing browning and retaining the firmness. In initial stage pineapple pieces were treated with individual chemical and based on the visual observation, four chemical preservatives were selected for further studies. Eight combinations of four chemical preservatives were selected for minimal processing of pineapple (Table 1). The pineapple pieces were dipped in different combination of preservatives for a period of $10 \mathrm{~min}$, after which they were drained out from solution, packed in 200 gauge LDPE packaging material and stored at both ambient and refrigerated storage condition.

Quality parameters viz., firmness, colour, $\mathrm{pH}$ and vitamin $\mathrm{C}$ content were evaluated at three days interval. Based on these properties best treatment combination was selected and analyzed for gas composition and microbial population.

\section{Firmness}

Instrumental texture analysis of the minimally processed fruit was measured in three days interval by using Texture analyzer (Model: 
TA.XT2) by the following test conditions/setting.

Sample was placed on heavy duty platform and probe was lowered down to press the sample and corresponding force deformation curve was plotted. Firmness or hardness is the most important quality parameter for fruits and vegetables. Firmness which indicates the force required by the probe to crush the fruit piece was obtained at y axis corresponding to highest peak in the graph. Each sample was tested with three replicates and values were used in the data analysis (Wu et al., 2012).

\section{Colour}

Colour of pineapple contributes more to the assessment of quality by the consumer than any other single factor. The colour was measured using CIELAB scale at $10^{\circ}$ observer and D65 illuminant (Bierhals et al., 2011) in Colour flex meter (Hunter Associates Laboratory, Inc., model: 65/10 ${ }^{\circ}$.

The colour values in terms of $\mathrm{L}^{*}, \mathrm{a}^{*}$ and $\mathrm{b}^{*}$ were recorded and the total colour change $(\Delta E)$ from the fresh samples was calculated using the following equation.

$$
\Delta E=\sqrt{\left(L-L_{0}\right)^{2}+\left(a-a_{0}\right)^{2}+\left(b-b_{0}\right)^{2}}
$$

The subscript " 0 " in the equation represents the colour value of fresh sample.

\section{Vitamin C (mg.100g $\left.{ }^{-1}\right)$}

Vitamin $\mathrm{C}$ content was estimated by volumetric method. The amount of ascorbic acid present in the sample was calculated as per the procedure described by Sadashivam and Manickam (1992).

\section{pH}

The $\mathrm{pH}$ of minimally processed samples was measured by using digital $\mathrm{pH}$ meter. Ten gram sample was weighed and it was extracted with $20 \mathrm{ml}$ of distilled water, then the electrode of the $\mathrm{pH}$ meter was dipped in the sample under test. All the readings were taken in triplicate.

\section{Decay factor}

Decay factor of minimally processed all the fruit samples were determined by one to five scale score card.

\section{Head space gas analysis}

Head space gas analysis was done at regular intervals, with the help of a needle inserted through a rubber septum on the packaging materials. The needle was connected to a $\mathrm{CO}_{2} / \mathrm{O}_{2}$ gas analyzer (PBI Dansensor Checkmate, Denmark), to measure the gas composition of $\mathrm{O}_{2}$ and $\mathrm{CO}_{2}$ in volumetric fraction (Iqbal et al., 2008).

\section{Microbial analysis}

Changes in the microbial population of freshcut pineapple wasstudied by total plate count at two days of interval.

\section{Statistical analysis}

All the experiments in the study were conducted in triplicate and mean values were reported. Factorial completely randomised design (FCRD) was used to analyse the data. After proper analysis, data were accommodated in the tables as per the needs of objectives for interpretation of results. Statistical significance of the terms in the regression equation was examined by analysis of variance (ANOVA) for each response. The p-values were used as a tool to check the significance of each of the coefficients, which, in turn were necessary to understand the pattern of the mutual interactions between the test variables. 


\section{Results and Discussion}

All the quality parameters were evaluated at two days interval for selecting the best combination.Fresh colour values of fresh pineapple samples were 77.06, 7.05 and 47.46 for $\mathrm{L}^{*}, \mathrm{a}^{*}$ and $\mathrm{b}^{*}$, respectively.

Effect of chemical preservatives and storage period on colour value of pineapple $L^{*}$ values of minimally processed pineapple

The $L *$ values of preservative treated refrigerated stored pineapple ranged from 77.52 to 59.85 at different storage period (Table 3 ). The highest $L^{*}$ value was recorded in sodium benzoate and citric acid treated samples, while lower value was in $\mathrm{CaCl}_{2}$ and citric acid treated samples. As the storage period increased, $L^{*}$ value decreased irrespective of treatments. The $L^{*}$ values of ambient stored pineapple ranged from 75.27 to 58.31. It was revealed that, the highest $L^{*}$ value was recorded at combination of sodium chloride, sodium benzoate and citric acid treated sample, lower value was observed for control samples. It is also evidenced from the table 3, except $\mathrm{NaCl}$ treated samples, the $L^{*}$ value decreased with storage period. The highest reduction in $L^{*}$ value was observed in control samples and lowest reduction noted with $\mathrm{SA}+\mathrm{CA}$ treated and $\mathrm{NaCl}$ treated sample. It was evident that, treatment combination, storage condition and storage period had significant effect on $L^{*}$ value of cut pineapple pieces. The variation in $L^{*}$ value was due to the development of translucency, rather than tissue browning. Similar results were reported by Montero-Calderon et al., (2008) for cut pineapple pieces stored in different packaging materials and Marrero and Kader (2006) for modified atmospheric storage pineapple.

\section{$a^{*}$ values of minimally processed pineapple}

In refrigerated condition lowest $\mathrm{a}^{*}$ value of 0.225 was observed for treatment $T_{3}$ combination on $3^{\text {rd }}$ day and the highest $a^{*}$ value of 8.39 was recorded in $T_{7}$ treatment. In most of the treatments $a^{*}$ value decreased with storage period as compare to fresh sample. In case of $\mathrm{T}_{7}$ treatment there was a slight increase in $a^{*}$ value on $3^{\text {rd }}$ day but gradually decreased with further storage period. In case of ambient storage condition there was decrease in $a^{*}$ value as compare to fresh sample. The highest reduction was observed for $\mathrm{T}_{3}$ treatment on $3^{\text {rd }}$ day (Table $3)$. The reduction of $a^{*}$ value indicated a reduced yellow colour in most of the treatments during the storage period.

\section{b* value of minimally processed pineapple}

The $b^{*}$ value of treated pineapple sample ranged from 57.78 to 10.05 over the storage period. It is clear from table 3 , the $b^{*}$ value of minimally processed pineapple increased initially and a drastic reduction was observed on further increase in storage period (after $3^{\text {rd }}$ day). Similar trend was observed in ambient storage condition with a maximum $b^{*}$ value of 57.38 in $T_{1}$ treatment and minimum of 13.77 in control sample. This indicated the changes in translucent appearance of the fruit flesh, which changed from a yellow-white opaque colour to a translucent yellow colour. It was clear that, changes in colour parameters of all the samples were due to translucency development rather than tissue browning. Similar trend was reported by Latifah et al., (1999) and Montero-Calderon et al., (2008) for cut pineapple pieces.

\section{Colour deviation $(\Delta E)$ of minimally processed pineapple}

Colour deviation was determined during the storage period in both refrigerated and ambient storage condition. In refrigerated storage condition minimum colour deviation was observed as 31.79 in $T_{7}$ treatment on $9^{\text {th }}$ day and maximum deviation observed was 40.47 in control sample on $9^{\text {th }}$ day of 
refrigerated storage (Fig. 1). In ambient condition, the lowest $\Delta E$ value of 25.80 was observed in $\mathrm{T}_{7}$ treatment on $3^{\text {rd }}$ day and highest $\Delta E$ value of 38.65 was observed in control sample on $6^{\text {th }}$ day of ambient storage condition. $\Delta E$ value of all the samples increased with storage period irrespective of storage condition and treatment. The highest deviation was observed in control samples at both storage conditions. It indicated that preservative treatment and refrigerated storage reduced the colour change during the storage. Statistical analysis indicated that, all the pretreatment, storage condition and storage period had significant effect in $\Delta E$ value $(\mathrm{p}<0.0001)$

\section{Firmness of minimally processed pineapple}

The initial value of firmness for fresh pineapple was $9.96 \mathrm{~N}$. Firmness of pineapple during storage ranged from 9.85 to $4.30 \mathrm{~N}$ and 4.35 to $2.00 \mathrm{~N}$, under refrigerated and ambient condition, respectively. It is clear from table 4 that firmness value decreased during the storage period. The highest firmness value was observed in sample treated with $\mathrm{CaCl}_{2}$ and $\mathrm{CAat}$ refrigerated storage condition on $9^{\text {th }}$ day of storage. However the lowest value observed for samples pre-treated with $\mathrm{NaCl}$. In case of ambient storage, $\mathrm{T}_{2}$ had highest firmness and control sample had the lowest firmness at the end of $6^{\text {th }}$ day of storage. The rapid loss of firmness was related to degradation of pectin, losses in visual appearance, deterioration and browning of pineapple slices. Reported values were in line with the studies of MonteroCalderon et al., (2008) for minimally processed pineapple pieces. It can also be observed from the table 4, that the $\mathrm{CaCl}_{2}$ treated samples maintained a better firmness compared to the other pre-treated samples. Similar trendwas reported by Gonzalez-Aguilar et al., (2004) for cut pineapple pieces.
Vitamin $\mathrm{C}$ content of minimally processed pineapple

Vitamin $\mathrm{C}$ content under refrigerated condition varied from 4.07 to $20.41 \mathrm{mg} .100 \mathrm{~g}^{-1}$, under ambient storage condition it varied from 4.93 to 17.01 mg. $100 \mathrm{~g}^{-1}$. The highest vitamin $\mathrm{C}$ content was recorded in $T_{1}$ treatment (both under refrigerated and ambient condition) and the lowest was in control samples (ambient storage).

It is clear from Figure 2 that the vitamin $\mathrm{C}$ concentration decreased drastically as the storage period increased in both storage condition. Similar trend was reported by Latifah et al., (1999) for cut pineapple pieces and El-Ishaq and Obirinakem (2015) for pineapple juice. As compared to control sample, all the samples had the highest vitamin $\mathrm{C}$ content due to presence of $\mathrm{CaCl}_{2}$, $\mathrm{SB}$ and $\mathrm{CA}$. These anti browning and anti microbial agents help to retain the vitamin $\mathrm{C}$ content in treated samples. But $\mathrm{NaCl}$ treated sample did not show much retention of vitamin $\mathrm{C}$ content, which might be due to the absence of firming agent. In absence of firming agent, there was juice leakage that resulted in reduced vitamin $\mathrm{C}$ content. Statistical analysis also indicated that, preservatives, storage condition and storage life had significant $(\mathrm{p}<0.0001)$ effect on vitamin $\mathrm{C}$ concentration.

\section{pH of minimally processed pineapple}

Preservative treatment and storage period had no significant effect on $\mathrm{pH}$ value. The $\mathrm{pH}$ value of preservative treated sliced pineapple samples showed decreased $\mathrm{pH}$ when compared to control samples. During storage, $\mathrm{pH}$ value decreased in initial days and later it increased. Results were in agreement with the results of Bartolome et al., (1996) and Latifah et al., (1999) for various variety of pineapple. 
$\mathrm{pH}$ value indicate the acidity, value of $\mathrm{pH}$ decreased with prolonged storage, probably due to the utilisation of organic acid as a respiratory substrate via the Krebs tricarboxylic acid cycle (Latifah et al., 1999).

\section{Decay score}

According to the five point score card, visual observations were made for decay score. Results of decay score is given in table 6. On $6^{\text {th }}$ day of ambient storage condition all the samples were spoiled due to juice leakage and reduced firmness, while, in case of refrigerated storage conditions, minimally processed pineapple maintained good colour and texture till $9^{\text {th }}$ day.

Based on the quality parameters and decay factor,two best treatmentsie., $\mathrm{T}_{1}\left(\mathrm{CaCl}_{2}+\mathrm{SB}\right)$ and $\mathrm{T}_{7} \quad(\mathrm{NaCl}+\mathrm{CA}+\mathrm{SB})$ treatment with refregeration condition were selected for futher microbial studies and head space gas analysis.

\section{Effect of storage days on head space gas concentration}

Head space gas concentration of minimally processed pineapple in ambient and refrigeration condition was analysed and results are given in table 7 . As the storage period increased there was significant decrease in the $\mathrm{O}_{2}$ level and increase in $\mathrm{CO}_{2}$ level.Head space $\mathrm{O}_{2}$ in ambient storage sample decreases from $20.90 \%$ to $0.27 \%$ and to $10.80 \%$ in refrigerated conditionon $3^{\text {rd }}$ day of storage. Slow changes in headspace $\mathrm{O}_{2}$ composition in could be explained by the low respiration rate of pineapple in refrigeration storage (Montero-Calderon et al., 2008). Anaerobic respiration of pineapple in atmospheric stored sample has created offflavors and off-odours. The partial pressure of $\mathrm{O}_{2}$ when decreased below the fermentation threshold limit, would lead to anaerobic respiration, which resulted in correspondingproduction of off-flavors and off-odorsin ambient storage sample (SolivaFortuny et al., 2004).

The level of $\mathrm{CO}_{2}$ increased from $0.03 \%$ to $80.90 \%$ and $5.10 \%$ in ambient and refrigerated storage conditions, respectively. The very high level of $\mathrm{CO}_{2}$ at ambient storage shows the significant effect of storage condition on $\mathrm{CO}_{2}$ production. During the storage period high initial rate of $\mathrm{CO}_{2}$ was due to wounding and a short-lived stress response rate at ambient condition (Finnegan et al., 2013). Similar result was reported by Marrero and Kader, (2006) in case of fresh-cut pineapples. At the end of storage period, $\mathrm{O}_{2}$ concentration increased and $\mathrm{CO}_{2}$ concentration showed a decreasing trend, due to permeability of packaging materials.

\section{Microbial analysis for best samples}

The microbial analysis was carried out for the best two samples stored in refrigeration storage. The microbial analysis for $T_{1}$ and $T_{7}$ minimally processed pineapple sample was found to be safe up to twelve days of storage period (Table 8). Total plate count for $\mathrm{T}_{1}$ treatment was $48 \times 10^{4} \mathrm{cfu} / \mathrm{g}$ and $\mathrm{T}_{7}$ treatment was $36 \times 10^{4} \mathrm{cfu} / \mathrm{g}$ on $12^{\text {th }}$ day of refrigerated storage. As per the FSSAI standard maximum permissible microbial limits of aerobic colony count for cut or minimally processed and packed (nonthermally processed) fruit and vegetables was $1 \times 10^{6} \mathrm{cfu} / \mathrm{gm}$. In present study microbial limit was within the limit set by FSSAI. Therefore sample was said to be microbially safe even after $9^{\text {th }}$ day of storage.

In conclusion, the combination of preservatives, storage condition and storage period had significant effect on quality of minimally processed pineapple. Shelf life of 
minimally processed pineapple in ambient condition was less than three day and in refrigerated condition it was nine days. Refrigeration condition with preservative treatment increased the shelf life to more than four times than that in ambient condition. The best preservative combination selected based on good retention of vitamin $\mathrm{C}$, colour and texture were $\mathrm{T} 1 \quad\left(\mathrm{CaCl}_{2}+\mathrm{SB}\right)$ and $\mathrm{T} 7$ $(\mathrm{NaCl}+\mathrm{CA}+\mathrm{SB})$. The best preservative treatments and refrigeration condition were also efficient in suppressing growth of microorganisms and production of $\mathrm{CO}_{2}$ during storage period.

Table.1 Combination of chemical preservatives for minimal processing of pineapple

\begin{tabular}{|l|l|l|}
\hline Sl. No. & Treatment & \\
\hline $\mathbf{1}$ & $\mathrm{T}_{\mathrm{c}}$ & $\mathrm{Control}$ \\
\hline $\mathbf{2}$ & $\mathrm{T}_{1}$ & $\mathrm{CaCl}_{2}+\mathrm{SB}$ \\
\hline $\mathbf{3}$ & $\mathrm{T}_{2}$ & $\mathrm{CaCl}_{2}+\mathrm{CA}$ \\
\hline $\mathbf{4}$ & $\mathrm{T}_{3}$ & $\mathrm{SB}+\mathrm{CA}$ \\
\hline $\mathbf{5}$ & $\mathrm{T}_{4}$ & $\mathrm{CaCl}_{2}+\mathrm{SB}+\mathrm{CA}$ \\
\hline $\mathbf{6}$ & $\mathrm{T}_{5}$ & $\mathrm{NaCl}+\mathrm{SB}$ \\
\hline $\mathbf{7}$ & $\mathrm{T}_{6}$ & $\mathrm{NaCl}+\mathrm{CA}$ \\
\hline $\mathbf{8}$ & $\mathrm{T}_{7}$ & $\mathrm{NaCl}+\mathrm{CA}+\mathrm{SB}$ \\
\hline $\mathbf{9}$ & $\mathrm{T}_{8}$ & $\mathrm{NaCl}$ \\
\hline
\end{tabular}

$* \mathrm{CaCl}_{2}: 1 \%$ Calcium chloride; SB: $0.05 \%$ Sodium benzoate; CA: $1 \%$ Citric Acid; NaCl: $1 \%$ Sodium chloride

Table.2 Test settings of the texture analyzer to determine the firmness

\begin{tabular}{|l|l|}
\hline Test mode & Return to start \\
\hline Pre test speed & $2.00 \mathrm{~mm} / \mathrm{s}$ \\
\hline Test speed & $2.00 \mathrm{~mm} / \mathrm{s}$ \\
\hline Post test speed & $2.00 \mathrm{~mm} / \mathrm{s}$ \\
\hline Distance & $10 \mathrm{~mm}$ \\
\hline Trigger force & $10 \mathrm{~g}$ \\
\hline Load cell & $50 \mathrm{~kg}$ \\
\hline Probe & $5 \mathrm{~mm}$ cylindrical probe \\
\hline
\end{tabular}


Table.3 Colour values of minimally processed pineapple

\begin{tabular}{|c|c|c|c|c|c|c|c|c|c|c|c|c|c|c|c|}
\hline \multirow[b]{3}{*}{ Treatments } & \multicolumn{5}{|c|}{$\mathbf{L}^{*}$} & \multicolumn{5}{|c|}{$\mathbf{a}^{*}$} & \multicolumn{5}{|c|}{$\mathbf{b}^{*}$} \\
\hline & \multicolumn{3}{|c|}{ Refrigerated storage } & \multicolumn{2}{|c|}{ Ambient storage } & \multicolumn{3}{|c|}{ Refrigerated storage } & \multicolumn{2}{|c|}{ Ambient storage } & \multicolumn{3}{|c|}{ Refrigerated storage } & \multicolumn{2}{|c|}{ Ambient storage } \\
\hline & $\begin{array}{l}3^{\text {rd }} \\
\text { Day }\end{array}$ & $\begin{array}{l}6^{\text {th }} \\
\text { Day }\end{array}$ & $\begin{array}{l}9^{\text {th }} \\
\text { Day }\end{array}$ & $3^{\text {rd }}$ Day & $6^{\text {th }}$ Day & $\begin{array}{l}3^{\text {rd }} \\
\text { Day }\end{array}$ & $\begin{array}{l}6^{\text {th }} \\
\text { Day }\end{array}$ & $\begin{array}{l}9^{\text {th }} \\
\text { Day }\end{array}$ & $\begin{array}{l}3^{\text {rd }} \mathrm{Da} \\
\mathrm{y}\end{array}$ & $6^{\text {th }}$ Day & $\begin{array}{l}3^{\text {rd }} \\
\text { Day }\end{array}$ & $\begin{array}{l}6^{\text {th }} \\
\text { Day }\end{array}$ & $\begin{array}{l}9^{\text {th }} \\
\text { Day }\end{array}$ & $3^{\text {rd }}$ Day & $6^{\text {th }}$ Day \\
\hline Control & 74.57 & 70.05 & 60.96 & 64.25 & 58.51 & 1.22 & 1.18 & 0.57 & 2.04 & 3.30 & 50.87 & 13.67 & 10.90 & 44.05 & 13.77 \\
\hline $\mathrm{CaCl}_{2}+\mathrm{SB}$ & 76.74 & 69.99 & 65.20 & 73.98 & 68.46 & 3.35 & 1.10 & 1.39 & 3.04 & 4.41 & 55.45 & 17.27 & 12.07 & 57.38 & 20.86 \\
\hline $\mathrm{CaCl}_{2}+\mathrm{CA}$ & 73.29 & 59.85 & 60.46 & 70.27 & 64.70 & 3.25 & 4.60 & 3.02 & 6.63 & 4.09 & 51.21 & 22.57 & 15.03 & 48.12 & 20.49 \\
\hline $\mathrm{SB}+\mathrm{CA}$ & 77.03 & 77.52 & 71.76 & 71.74 & 72.74 & -0.23 & 1.15 & 1.35 & 1.98 & 2.07 & 41.28 & 16.69 & 12.05 & 29.39 & 16.58 \\
\hline $\begin{array}{l}\mathrm{CaCl}_{2}+\mathrm{SB}+\mathrm{C} \\
\mathrm{A}\end{array}$ & 71.68 & 73.88 & 61.79 & 68.90 & 65.13 & 8.39 & 2.14 & 1.75 & 4.41 & 4.03 & 57.78 & 17.60 & 11.58 & 55.22 & 16.43 \\
\hline $\mathrm{NaCl}+\mathrm{SB}$ & 73.97 & 74.06 & 70.53 & 73.51 & 70.68 & 5.53 & 2.28 & 1.36 & 4.07 & 3.44 & 53.92 & 18.30 & 13.08 & 45.10 & 21.83 \\
\hline $\mathrm{NaCl}+\mathrm{CA}$ & 75.85 & 75.67 & 61.98 & 75.07 & 67.41 & 4.21 & 1.72 & 0.70 & 7.33 & 5.93 & 49.06 & 20.70 & 14.73 & 45.31 & 22.92 \\
\hline $\mathrm{NaCl}+\mathrm{CA}+\mathrm{SB}$ & 72.90 & 68.47 & 69.12 & 75.27 & 70.65 & 3.72 & 4.30 & 3.24 & 8.38 & 6.08 & 43.07 & 23.29 & 16.91 & 42.93 & 18.91 \\
\hline $\mathrm{NaCl}$ & 75.97 & 75.44 & 69.79 & 66.73 & 68.95 & 1.46 & 1.24 & 0.79 & 4.86 & 2.77 & 49.26 & 14.39 & 10.05 & 48.19 & 18.87 \\
\hline & \multicolumn{2}{|c|}{ Sd. Dev.: } & 2.34 & Sd. Dev.: & 2.25 & Sd. De & \multicolumn{2}{|c|}{0.23} & Sd. Dev.: & 0.26 & Sd. Dev. & \multicolumn{2}{|c|}{1.08} & Sd. Dev.: & 1.16 \\
\hline & p-value & & .0001 & p-value: & $<0.0001$ & p-value & $<0$. & 001 & p-value: & $<0.0001$ & p-value: & $<0.0$ & & p-value: & $<0.0001$ \\
\hline
\end{tabular}


Table.4 Firmness (N) value of minimally processed pineapple

\begin{tabular}{|l|l|l|l|l|l|}
\hline & \multicolumn{3}{l}{ Refrigerated storage } & \multicolumn{2}{l|}{ Ambient storage } \\
\hline & $3^{\text {rd }}$ Day & $6^{\text {th }}$ Day & $9^{\text {rd }}$ Day & $3^{\text {rd }}$ Day & $6^{\text {th }}$ Day \\
\hline Control & 4.88 & 4.58 & 4.43 & 2.70 & 2.00 \\
\hline $\mathbf{C a C l}_{2}+\mathbf{S B}$ & 9.85 & 7.82 & 6.22 & 3.77 & 3.25 \\
\hline $\mathbf{C a C l}_{2}+\mathbf{C A}$ & 7.42 & 7.40 & 7.38 & 4.35 & 3.70 \\
\hline $\mathbf{S B}+\mathbf{C A}$ & 5.21 & 5.03 & 4.74 & 3.14 & 2.75 \\
\hline $\mathbf{C a C l}_{\mathbf{2}}+\mathbf{S B}+\mathbf{C A}$ & 6.74 & 5.92 & 5.38 & 3.76 & 3.33 \\
\hline $\mathbf{N a C l}_{+} \mathbf{S B}$ & 6.47 & 6.05 & 5.31 & 3.14 & 2.73 \\
\hline $\mathbf{N a C l}+\mathbf{C A}$ & 6.59 & 6.24 & 5.86 & 3.56 & 3.19 \\
\hline $\mathbf{N a C l}+\mathbf{C A}+\mathbf{S B}$ & 6.57 & 6.15 & 5.70 & 3.49 & 3.10 \\
\hline $\mathbf{N a C l}$ & 4.57 & 4.43 & 4.30 & 2.95 & 2.61 \\
\hline & Sd. Dev. & 1.96 & Sd. Dev. & 1.53 \\
\hline & p-value & $<0.0001$ & p-value & $<0.0001$ \\
\hline
\end{tabular}

Table.5 pH of minimally processed pineapple

\begin{tabular}{|l|l|l|l|l|l|l|}
\hline & \multicolumn{4}{|l|}{ Refrigerated storage } & \multicolumn{2}{l|}{ Ambient storage } \\
\hline & $\mathbf{1}^{\text {st }}$ Day & $\mathbf{3}^{\text {rd }}$ Day & $\mathbf{6}^{\text {th }}$ Day & $\mathbf{9}^{\text {th }}$ Day & $\mathbf{3}^{\text {rd }}$ Day & $\mathbf{6}^{\text {th }}$ Day \\
\hline Control & 4.6 & 4.40 & 4.20 & 4.60 & 4.48 & 4.73 \\
\hline $\mathbf{C a C l}_{2}+\mathbf{S B}$ & 4.62 & 4.16 & 4.18 & 4.18 & 4.16 & 4.20 \\
\hline $\mathbf{C a C l}_{\mathbf{2}}+\mathbf{C A}$ & 4.61 & 3.97 & 3.97 & 3.98 & 4.05 & 4.11 \\
\hline $\mathbf{S B}+\mathbf{C A}$ & 4.58 & 3.96 & 3.99 & 3.98 & 4.07 & 4.14 \\
\hline $\mathbf{C a C l}_{\mathbf{2}}+\mathbf{S B}+\mathbf{C A}$ & 4.62 & 4.26 & 4.30 & 4.32 & 4.32 & 4.38 \\
\hline $\mathbf{N a C l + S B}$ & 4.63 & 4.29 & 4.32 & 4.34 & 4.38 & 4.41 \\
\hline $\mathbf{N a C l + C A}$ & 4.57 & 3.81 & 3.84 & 3.87 & 4.13 & 4.17 \\
\hline $\mathbf{N a C l}+\mathbf{C A}+\mathbf{S B}$ & 4.59 & 3.86 & 3.90 & 3.93 & 4.34 & 4.39 \\
\hline $\mathbf{N a C l}$ & 4.55 & 3.92 & 3.95 & 3.99 & 4.25 & 4.28 \\
\hline & Sd. Dev. & & 0.24 & & Sd. Dev. & 0.28 \\
\hline & p-value & & $<0.05$ & & p-value & $>0.05$ \\
\hline
\end{tabular}


Table.6 Decay score* of minimally processed pineapple

\begin{tabular}{|l|c|l|l|l|l|l|}
\hline & & \multicolumn{3}{|l|}{ Refrigerated storage } & \multicolumn{2}{l|}{ Ambient storage } \\
\hline & $\mathbf{1}^{\text {st }}$ Day & $\mathbf{3}^{\text {rd }}$ Day & $\mathbf{6}^{\text {th }}$ Day & $\mathbf{9}^{\text {th }}$ Day & $\mathbf{3}^{\text {rd }}$ Day & $\mathbf{6}^{\text {th }}$ Day \\
\hline Control & 1 & 2.00 & 2.00 & 3.00 & 3.00 & 5.00 \\
\hline $\mathbf{C a C l}_{2}+\mathbf{S B}$ & 1 & 1.00 & 1.00 & 1.00 & 3.00 & 3.00 \\
\hline $\mathbf{C a C l}_{\mathbf{2}}+\mathbf{C A}$ & 1 & 1.00 & 1.00 & 2.00 & 3.00 & 4.00 \\
\hline $\mathbf{S B}+\mathbf{C A}$ & 1 & 1.00 & 1.00 & 2.00 & 3.00 & 4.00 \\
\hline $\mathbf{C a C l}_{2}+\mathbf{S B}+\mathbf{C A}$ & 1 & 1.00 & 1.00 & 2.00 & 3.00 & 4.00 \\
\hline $\mathbf{N a C l + S B}$ & 1 & 1.00 & 1.00 & 2.00 & 3.00 & 4.00 \\
\hline $\mathbf{N a C l + C A}$ & 1 & 1.00 & 1.00 & 2.00 & 3.00 & 4.00 \\
\hline $\mathbf{N a C l + C A + S B}$ & 1 & 1.00 & 1.00 & 1.00 & 3.00 & 4.00 \\
\hline $\mathbf{N a C l}$ & 1 & 1.00 & 1.00 & 2.00 & 3.00 & 4.00 \\
\hline
\end{tabular}

*1-No change; 2-Slight colour change but firm texture; 3-No juice leakage but reduced firmness and colour; 4-Juice leakage, colour changes and loss of firmness;5-Juice leakage, colour changes, loss of firmness and bulged packaging.

Table.7 Head space gas concentration in selected treatments

\begin{tabular}{|l|c|c|c|c|c|c|c|c|}
\hline & \multicolumn{4}{|c|}{ Ambient storage } & \multicolumn{5}{c|}{ Refrigerated storage } \\
\hline & $\mathbf{O}_{\mathbf{2}}$ & $\mathbf{O}_{\mathbf{2}}$ & $\mathbf{C O}_{\mathbf{2}}$ & $\mathbf{C O}_{\mathbf{2}}$ & $\mathbf{O}_{\mathbf{2}}$ & $\mathbf{O}_{\mathbf{2}}$ & $\mathbf{C O}_{\mathbf{2}}$ & $\mathbf{C O}_{\mathbf{2}}$ \\
\hline & $\mathbf{T}_{\mathbf{1}}$ & $\mathbf{T}_{\mathbf{7}}$ & $\mathbf{T}_{\mathbf{1}}$ & $\mathbf{T}_{\mathbf{7}}$ & $\mathbf{T}_{\mathbf{1}}$ & $\mathbf{T}_{\mathbf{7}}$ & $\mathbf{T}_{\mathbf{1}}$ & $\mathbf{T}_{\mathbf{7}}$ \\
\hline Initial & 20.90 & 20.90 & 0.03 & 0.03 & 20.90 & 20.90 & 0.03 & 0.03 \\
\hline $\mathbf{3}$ & 0.27 & 0.60 & 50.27 & 37.83 & 10.80 & 15.90 & 2.80 & 3.40 \\
\hline $\mathbf{5}$ & 23.47 & 32.53 & 70.47 & 80.90 & 7.03 & 7.37 & 5.10 & 4.70 \\
\hline $\mathbf{7}$ & 8.07 & 8.83 & 55.43 & 72.43 & 9.87 & 10.70 & 4.07 & 4.77 \\
\hline $\mathbf{9}$ & & & & & 18.40 & 16.83 & 2.00 & 2.47 \\
\hline $\mathbf{1 1}$ & & & & & 17.53 & 18.80 & 2.37 & 1.83 \\
\hline
\end{tabular}


Table.8 Microbial analysis of selected treatments

\begin{tabular}{|c|c|c|c|}
\hline Sl. No. & Sample & & Total plate count \\
\hline 1 & \multirow[t]{5}{*}{$\mathrm{T} 1$} & $1^{\text {st }}$ day & $45 \times 10^{4}$ \\
\hline 2 & & $3^{\text {rd }}$ day & $40 \times 10^{4}$ \\
\hline 3 & & $6^{\text {th }}$ day & $38 \times 10^{4}$ \\
\hline 4 & & $9^{\text {th }}$ day & $25 \times 10^{4}$ \\
\hline 5 & & $12^{\text {th }}$ day & $48 \times 10^{4}$ \\
\hline 6 & \multirow[t]{5}{*}{$\mathrm{T} 7$} & $1^{\text {st }}$ day & $46 \times 10^{4}$ \\
\hline 7 & & $3^{\text {rd }}$ day & $39 \times 10^{4}$ \\
\hline 8 & & $6^{\text {th }}$ day & $27 \times 10^{4}$ \\
\hline 9 & & $9^{\text {th }}$ day & $29 \times 10^{4}$ \\
\hline 10 & & $12^{\text {th }}$ day & $36 \times 10^{4}$ \\
\hline
\end{tabular}

Fig.1 Effect of minimal processing pretreatment and storage condition on $\Delta E$ value of pineapple
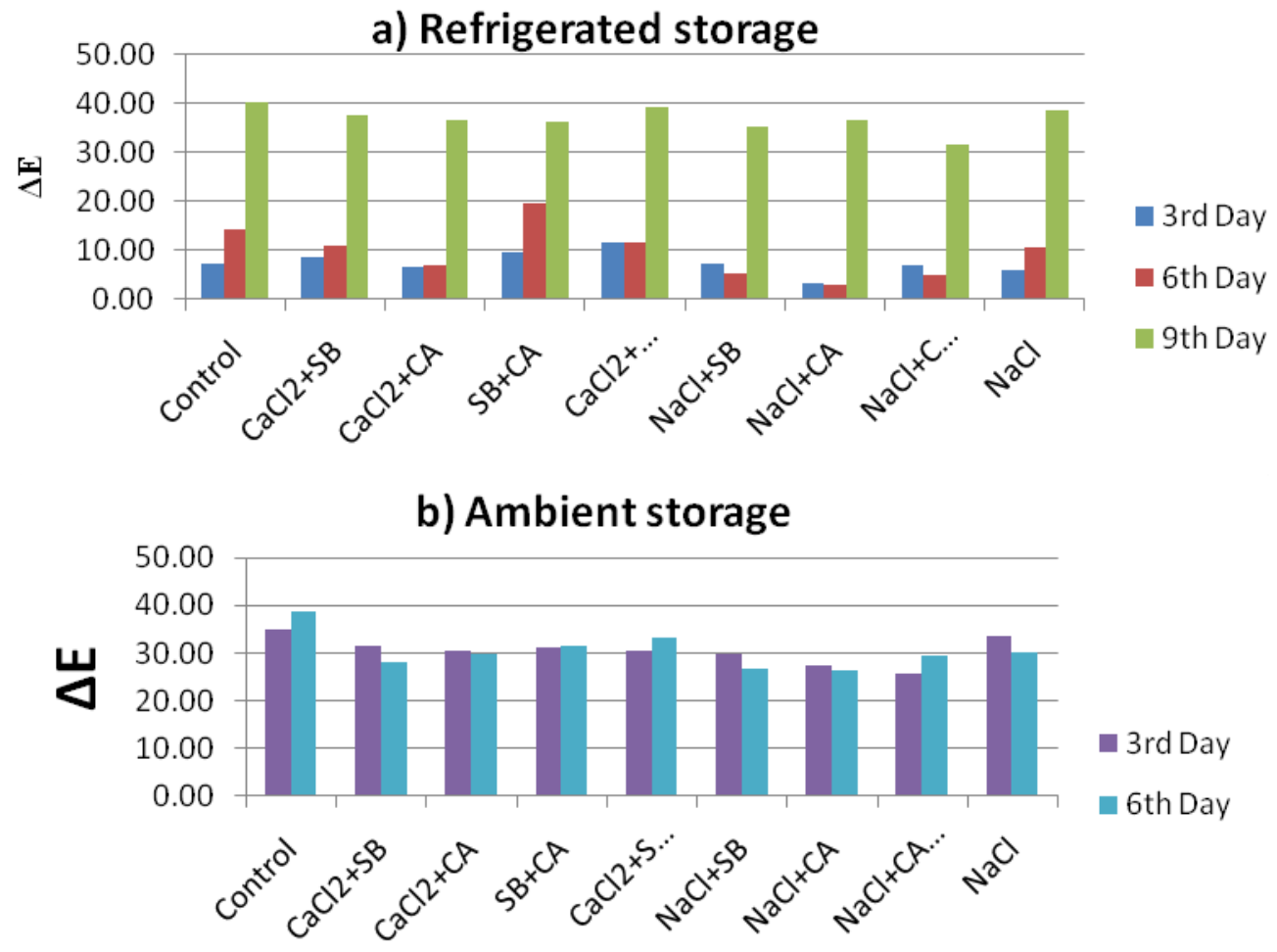
Fig.2 Effect of minimally processing pretreatment and storage condition on vitamin C

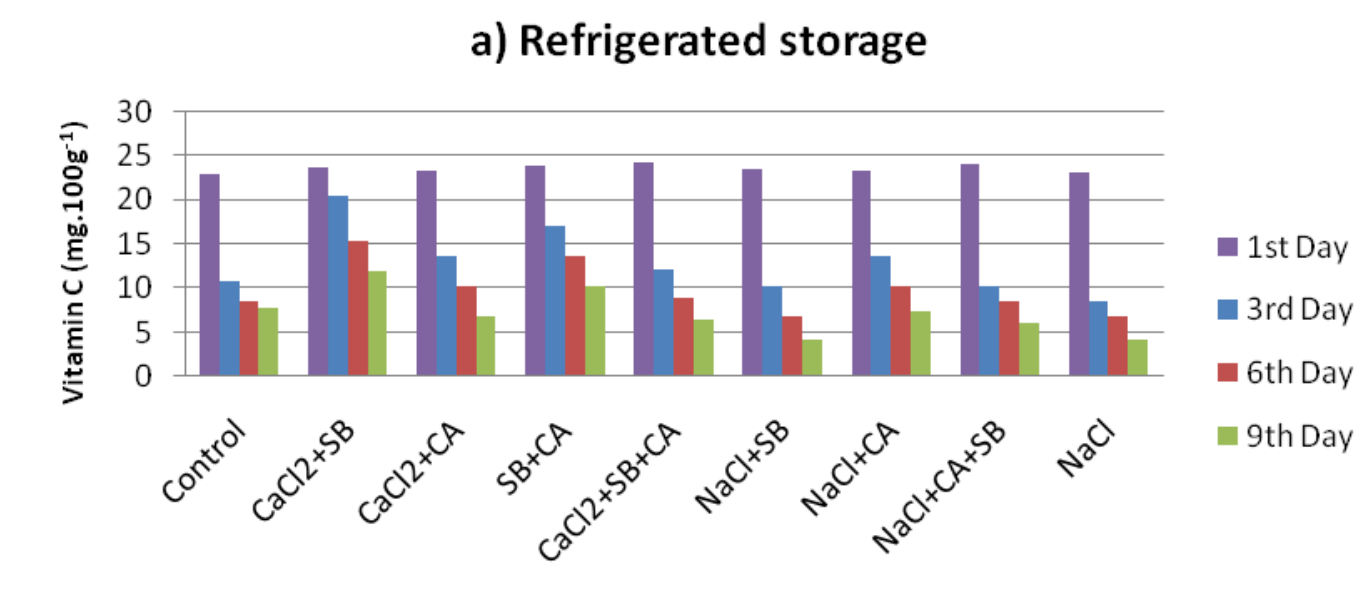

b) Ambient storage

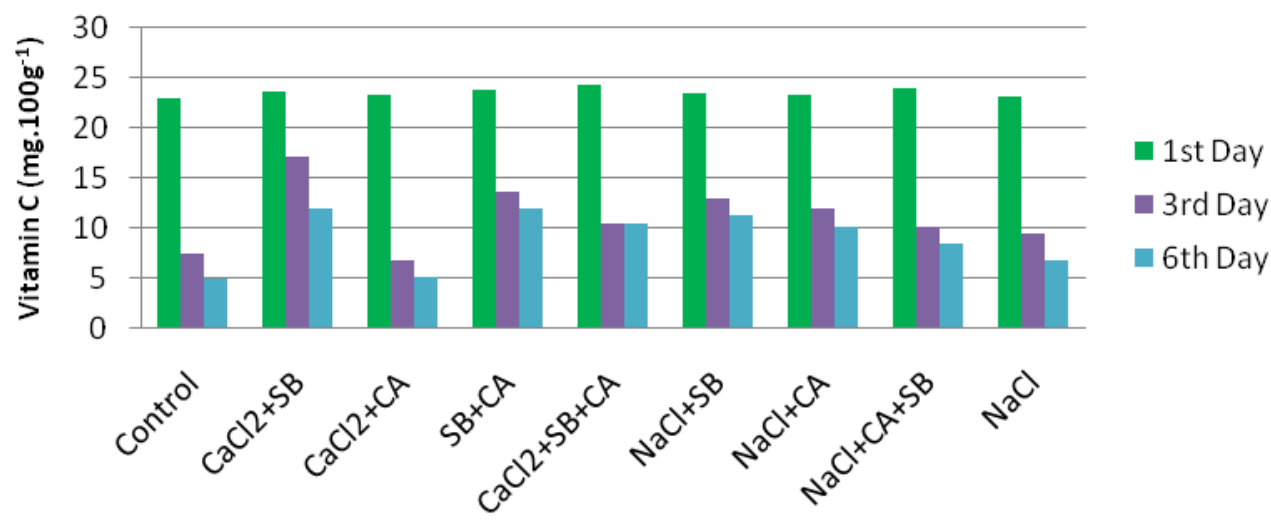

\section{Acknowledgement}

Present research work is financially assisted by Indian Council of Agricultural Research (ICAR) through National Fellow project.

\section{References}

Bartolome, A.P., Ruperez, P. and Instituto, C.F. 1996. Non-Volatile organic acids, $\mathrm{pH}$ and titratable acidity changes in pineapple fruit slices during frozen storage. J Sci. Food Agric. 70:475-480.

Benitez, S., Chiumenti, M., Sepulcre, F., Achaerandio, I. and Pujola, M. 2012. Modeling the effect of storage temperature on the respiration rate and texture of fresh cut pineapple. J. Food Eng. 113: 527-533.

Bierhals, V. S., Chiumarelli, M. and Hubinger, M. D. 2011. Effect of Cassava Starch Coating on Quality and Shelf Life of Fresh-Cut Pineapple (Ananas comosus L. Merril cv "Perola"). J. Food Sci., 76(1):E62-72.

Finnegana, E., Mahajanb, P.V., O'Connella, M., Francisa, G.A. and O'Beirne, D. 2013. Modelling respiration in fresh-cut pineapple and prediction of gas permeability needs for optimal modified atmosphere packaging. Postharvest Bio. Technol. 79: 47-53 
El-Ishaq, A. and Obirinakem, S. 2015. Effect of temperature and storage on vitamin $\mathrm{C}$ content in fruits juice. Int. J. Chemi Biomol. Sci. 1(2):17-21.

Gonzalez-Aguilar, G.A., Ruiz-Cruz, S., CruzValenzuela, R., Rodriguez-Felix, A. and Wang, C.Y. 2004. Physiological and quality changes of fresh-cut pineapple treated with antibrowning agents. $L W$. Technol. 37, 369-376.

Iqbal, T., Rodrigues, F.A.S., Mahajan, P.V., Kerry, J.P., Gil, L., Manso, M.C. and Cunha, L.M. 2008. Effect of Minimal processing conditions on respiration rate of carrots. J. Food Sci., 73 (8): E392402.

Latifah, M.N., Abdullah, H., Selamat, M. Talib, Y. and Rahman, K. M. 1999. Quality evaluation of minimally processed pineapple using two packing systems. J. Trop. Agric. Food Sci. 27(1): 101-107.

Manolopoulou, E. and Varzakas, T. 2011. Effect of storage conditions on the sensory quality, colour and texture of fresh-cut minimally processed cabbage with the addition of ascorbic acid, citric acid and calcium chloride. Food Nutr. Sci. 2: 956-963.

Marreroa, A. and Kader, A.A. 2006. Optimal temperature and modified atmosphere for keeping quality of fresh-cut pineapples. Postharvest Bio. Technol. 39: 163-168.

Montero-Calderon, M., Rojas-Grau, M.A. and
Martin-Belloso, O. 2008. Effect of packaging conditions on quality and shelf-life of fresh-cut pineapple (Ananas comosus). Postharvest Bio. Technol. 50 (3): 182-189.

O'connor-shaw, R.E., Robert, R., Ford, A.L., and Nottingham, S.M., 1994. Shelf life of minimally processes honeydew, kiwifruit, papaya, pineapple and cantaloupe. J. Food sci., 59(6):12021206.

Sadashivam, S. and Manickam, A. 1992. Biochemical methods for agricultural sciences. Wiley Eastern Ltd., New Delhi, pp 199-201.

Siddiqui, M. W., Chakraborty, I., AyalaZavala, J. F. and Dhua, R. S. 2011. Advances in minimal processing of fruits and vegetables: a review. J.S cient. Ind. Res.70:823-834.

Soliva-Fortuny, R.C., Alos-Saiz, N., EspachsBarroso, A. and Martín-Belloso, O. 2004. Influence of maturity at processing on quality attributes of freshcut conference pears. J. Food Sci., 69: 290-294.

Wu, Z., Zhanga, M. and Wang, S. 2012. Effects of high-pressure argon and nitrogen treatments on respiration, browning and antioxidant potential of minimally processed pineapples during shelf life. J. Sci. Food Agric., DOI: $10.1002 /$ jsfa.5612.

\section{How to cite this article:}

Sudheer, K.P., K.B. Sankalpa and Saranya, S. 2019. Effect of Preservatives and Temperature on Microbial and Physico-Chemical Attributes of Minimally Processed Pineapple. Int.J.Curr.Microbiol.App.Sci. 8(02): 541-553. doi: https://doi.org/10.20546/ijcmas.2019.802.062 